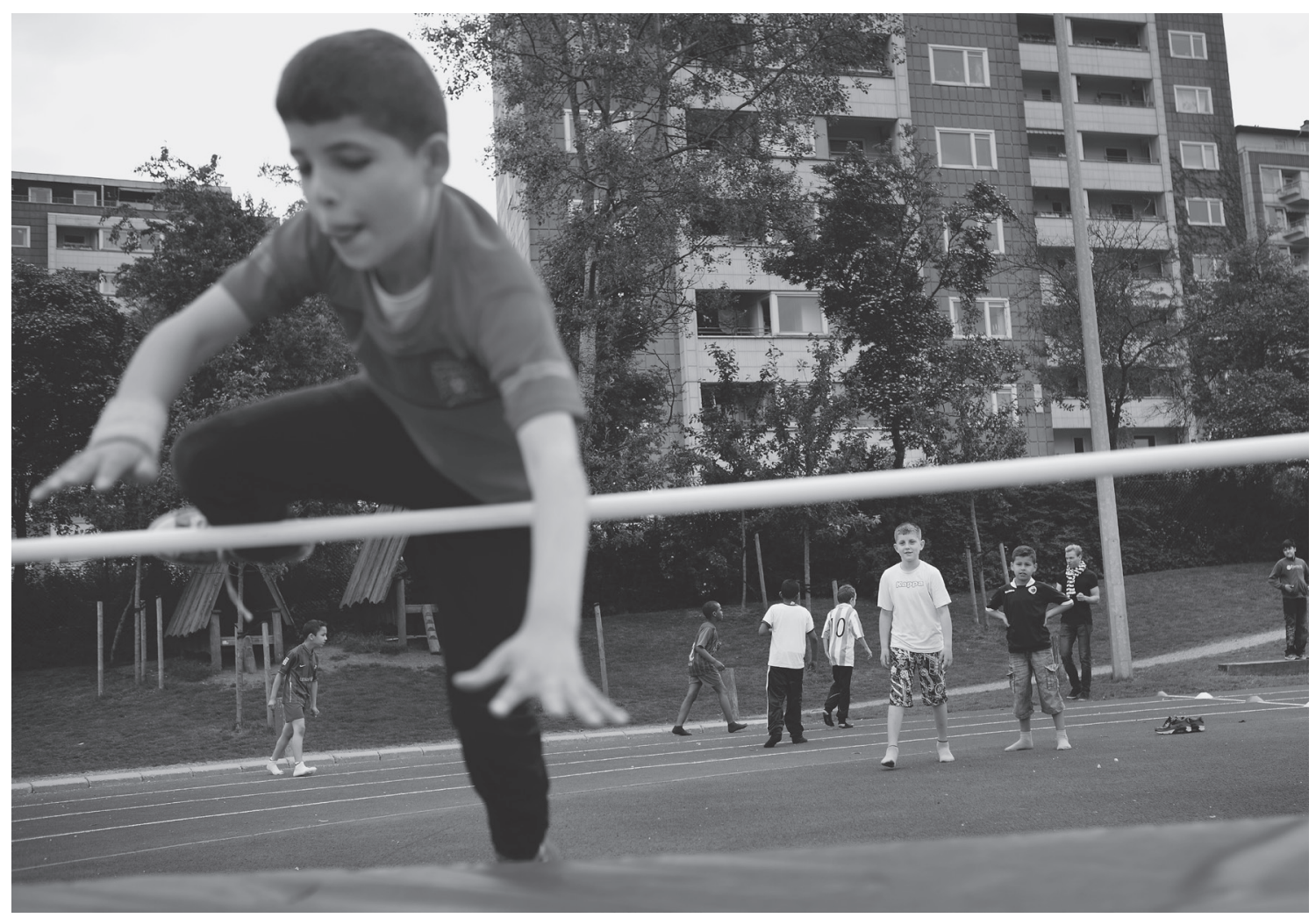

En svensk undersøgelse viser, at daglig idræt har stor betydning for især drenges skoleresultater (Foto: Scanpix Denmark/ Christian Als).

\title{
Tävlandet inom idrotten
}




\section{INLEDNING}

Den svenska beteendevetenskapliga idrottsforskningen växte fram och etablerades under 1970- och 1980-talen. Idrottsforskarna kom tidigt att ha åsikter om hur idrotten skulle utformas i skola och idrottsföreningar. Tävlandet inom idrotten, att somliga vann och andra förlorade, kom i fokus. Vid en konferens 1970 i Stockholm om skolans idrottsämne framhöll pedagogen Lars-Magnus Engström att "vi måste få alla elever att lyckas. Vi har nog hittills misslyckats med detta." ${ }^{1}$ En annan forskare, psykologen Torbjörn Stockfelt, efterlyste mer "konkurrensfria övningar" eftersom människor enligt hans uppfattning slutade idrotta när de "inte är konkurrenskraftiga längre". ${ }^{2}$

42 år senare föreläste psykologen Erwin Apitzsch i Umeå (i norra Sverige) över temat “idrottsföreningar utan tävlingsinslag”. Han var inbjuden av lokala politiker som oroades över att ungdomar lämnade föreningsidrotten. Vid föredraget förklarade Apitzsch att idrottsliga avbrott skulle minskas om nya idrottsföreningar startades upp "utan tävlingsinslag". Kommuner skulle också på olika sätt understödja "spontana idrottsaktiviteter". Det handlade om att “åstadkomma en livslång fysisk aktivitet under roliga former". ${ }^{3}$

I föreliggande artikel beskrivs och analyseras hur den beteendevetenskapliga idrottsforskningen i Sverige åren 1970-2010 behandlat "tävlingsidrotten", företrädesvis vid studier av barnoch ungdomsidrott. Jag uppmärksammar också idrottshistorisk forskning då deras stadieteorier påverkat samtidsorienterade idrottsforskares analyser av "tävlingsidrotten". Huvudintresset ägnas dock pedagogen Lars-Magnus Engström, en centralgestalt inom svensk idrottsforskning sedan 1970-talet, och de idrottsforskare som inspirerats av Engströms idrottsteoretiska reso- nemang, exempelvis pedagogerna Staffan Karp, Per Nilsson och Karin Redelius. Utgångspunkten är att idrottsforskare som Engström, Karp, Nilsson och Redelius inte bara analyserat idrott utan också påverkat hur den utvecklats i föreningar och skola. I det moderna samhället har, som bland annat Pierre Bourdieu framhållit, män och kvinnor inom vetenskapen en legitimitet och auktoritet som ger dem goda möjligheter att påverka opinioner och sakpolitik. Detta resonemang torde också vara giltigt för svenska idrottsforskare, och för hur deras kompetens efterfrågats och använts under de senaste 40 åren.

\section{TÄVLINGSIDROTTEN - EN INHUMAN KULTURYTTRING}

År 1969 presenterades betänkandet Idrott åt alla som i Sverige var startskottet för ett ökat statligt engagemang och ekonomiskt stöd till idrotten. ${ }^{4}$ Idrott var inte längre förbehållet män mellan 15-30 år utan nu skulle alla medborgare erbjudas en fysisk aktivitet som passade var och ens förutsättningar. Det övergripande målet var bättre folkhälsa (SOU 1969). Lars-Magnus Engström var, som visades inledningsvis, en av de idrottsforskare som åren kring 1970 deltog i debatten om hur idrott-åt-alla visionen skulle realiseras när det gällde barn och ungdomar. Han intog en relativt kritisk hållning till föreningsidrotten, eller som den ofta kallades, "tävlingsidrotten", och den "utslagning" som förekom här. ${ }^{5}$ I Engströms doktorsavhandling (1975) förklarades att tävlingsidrotten ur ett samhälleligt hälsoperspektiv var ett relativt ointressant fenomen och han förordade satsningar, inom såväl utbildningsväsendet som föreningsidrotten, som var inriktade på fysiska aktiviteter där de "rekreativa inslagen" var stora och individanpassade. "Ungdomarna skulle således ha möjligheter att anmäla sig till en förening eller motsvarande 
för att lära sig en färdighet och inte i första hand för att med hjälp av denna färdighet konkurrera med andra." (Engström 1975, s.45)

Kritiken skärptes några år senare med pedagogerna Hans Brunnbergs och Bert Aggestedts/ Ulla Tebelius doktorsavhandlingar. Inom idrotten fanns, förklarade Brunnberg, gemenskap men också, vilket stod i motsättning till gemenskapen, den "allvarliga" och konkurrensinriktade tävlingsverksamheten. Att förlora riskerade rubba självkänsla och identitetsuppfattning. Enligt Brunnberg premierade tävlandet aggressivitet, våld och en individualistisk mentalitet. "När kontakten i idrottsföreningen är uppnådd, får man genom idrottsutövandet utlopp för sina behov av att konkurrera, hävda sig, lyckas med något och vara aggressiv. Tillspetsat skulle jag vilja hävda att det är en bild av människan som asocial varelse som här skymtar fram.” (Brunnberg 1976, s. 52-53) Brunnberg rekommenderade idrottsrörelsen, och Sveriges politiker, att uppvärdera den lustbetonade, "expressiva” idrotten. I Aggestedts och Tebelius doktorsavhandling, där skolbarns upplevelser av idrott studerades, tog man avstånd från den maskinpräglade människosynen som fanns inom föreningsidrotten. Författarna var mycket kritiska till att föreningsidrotten tillåtits prägla skolidrotten. "Det finns inte många aktiviteter varken i skolan eller under fritiden, som på olika nivåer kan ha så exkluderande effekter och därav negativa upplevelser som idrott.” (Aggestedt \& Tebelius 1977: 2006)

De svenska idrottsforskarnas kritiska analyser av "tävlingsidrotten", och hur den påverkade barn och ungdomars idrottande, fortsatte under 1980- och 1990-talen samtidigt som en mer teoretiserande tendens gjorde sig gällande. En återkommande problematik var frågan om hur idrott skulle definieras. Utgångspunkten var ofta den breda definition som använts i 1969 års

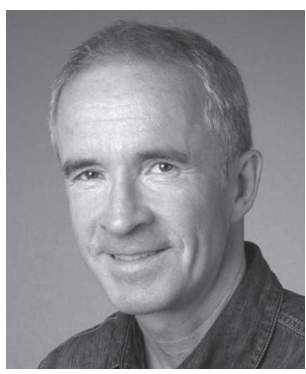

utredning Idrott åt alla och som politiker och idrottsrörelsens företrädare brukade använda. Enligt denna var nästan alla frivilligt valda fysiska aktiviteter, inklusive svampplockning, idrott. Det ansågs inte möjligt att göra någon skarp skillnad mellan en motionsbetonad form av idrottslig verksamhet och en mer tävlingsbetonad form. Likheterna var större än skillnaderna. Men denna vaga definition underkändes av idrottsforskarna. Här efterlystes en mer distinkt definition av idrottsbegreppet. Detta ledde också till ett ökat intresse för hur idrotten utvecklats historiskt. Genom att blicka bakåt kunde samtidens idrott bättre förstås.

\section{HISTORIKERNA OCH DEN MODERNA (TÄVLINGS-)IDROTTEN}

Den idrottshistoriska forskningen i Sverige, som också den kommit igång på allvar under 1970-talet, var inledningsvis tämligen deskriptiv. ${ }^{6}$ Här beskrevs äldre tiders fysiska tvekamper och överklassens bollspel. Begreppet "tävlingsidrott" och begrepp som "modern idrott" och "modern tävlingsidrott" användes som synonymer utan att definieras eller förankras teoretiskt. Det var ett allmänbegrepp hämtat från vardagsspråket som användes för att illustrera och beskriva en utveckling från och med 1800-talets slut med allt fler nya idrotter där organiserade tävlingar var ett dominerande inslag. 
Detta ateoretiska förhållningssätt övergavs under 1980- och 1990-talen. Bagrunden var den teoribildning som utvecklats internationellt där idrotten problematiserats utifrån olika samhälleliga utvecklings- och stadieteorier. Inom denna uppmärksammades exempelvis sambanden mellan det kapitalistiska fabrikssystemets krav på mätbarhet, prestationer och disciplinering och de likartade företeelser som fanns inom den moderna idrotten. De mer kritiskt och samtidsorienterade forskarna problematiserade idrottens funktion i det moderna samhället och hur idrotten bidrog till att reproducera och stärka rådande samhällsstrukturer.

Introduktionen av de idrottsliga stadieteorierna i Sverige under 1980-talet, särskilt den som lanserats av historikern Allen Guttmann, ledde till ett fördjupat intresse för vad som kännetecknade "modern sports", eller som det kom att heta på svenska, den "moderna tävlingsidrotten", inte "modern idrott" som hade varit en korrekt översättning. ${ }^{7}$ Översättningen innebar en innebördsförskjutning då "modern sports" var ett vidare begrepp än modern tävlingsidrott som fokuserade tävlingen på ett sätt som inte "modern sports" gjorde. Det här gällde i ännu högre grad när bestämningen "modern” utelämnades - vilket ofta var fallet - och man nöjde sig med "tävlingsidrott". Översättningen betydde att ett beprövat begrepp - den moderna tävlingsidrotten/tävlingsidrotten - integrerades i en internationell idrottshistorisk stadieteori och därmed fick ökad vetenskaplig legitimitet och status.

De idrottsliga stadieteorierna inspirerade till nya studier av den moderna idrottens genombrott och tillväxt i Sverige. Sportifieringsbegreppet, som hämtats från den norske historikern Matti Goksöyr, men också den finske sociologen Kalevi Häinilä's totaliseringsteori, användes för att analysera utvecklingen och påvisa den moderna tävlingsidrottens särart och allt starkare ställning.

Den idrottshistoriska problematiseringen var i Sverige i jämförelse med internationell forskning tämligen insnävad och kretsade ofta kring idrottens tävlingsverksamhet och de motsättningar som de historiska aktörerna hade i denna fråga. Studierna rörde svensk TÄVLINGS-idrott och inte så mycket den moderna idrotten som bred kulturföreteelse.

\section{IDROTTENS PRAKTIKER/LOGIKER}

De samtidsorienterade idrottsforskarnas försök att definiera idrott kretsade kring vad som var typiska karaktäristika för idrott och olika slags fysiska aktivitetsformer, historiskt, som berörts i föregående avsnitt, men framförallt bland de reellt existerande aktivitetsformerna. ${ }^{8}$ Det rörde dels manifesta karaktäristika, exempelvis om de fysiska aktiviteterna var regelstyrda och knutna till idrottsorganisationers verksamhet, dels mer subjektiva och meningsbärande karaktäristika där man utgick från varför människor - medvetet och omedvetet - valde vissa typer av fysiska inaktiviteter. Det handlade om att identifiera de olika meningsbärande kärnvärden som forskarna menade fanns, inom till exempel "tävlingsidrott", och hur dessa påverkade utövarnas värderingar och människosyn men också hur människor attraherades eller stöttes bort av dessa.

Lars-Magnus Engström var en av de mer inflytelserika forskarna när det gällde utarbetandet av idrottsdefinitioner och klassifikationsmodeller. ${ }^{9}$ Han hade redan 1975 lanserat en modell med sex olika fysiska aktivitetsformer. Fyra år senare, 1979, presenterades en modell med åtta, vilket 1983 reducerats till fem fysiska aktivitetsformer och 1989 reducerats ytterligare till tre: 
tävlings-, motions- och rekreationsidrott. Motions- och rekreationsidrott känntecknades enligt Engström av att utövarnas syfte var att få bättre hälsa och fysisk kapacitet samt ökat välbefinnandet. Något officiellt regelsystem eller andra bindande överenskommelser fanns oftast inte, inte heller något "uttalat tävlingsmoment". Motions- och rekreationsidrotten hade enligt Engström historiskt sina rötter i Linggymnastikens ideal om hälsofostran för alla medborgare samt allmogens folklekar och över- och medelklassens friluftsliv. Den avgörande skillnaden mellan motions- respektive rekreationsidrotten var att man inom motionsidrotten betonade det "nyttiga" medan tyngdpunkten inom rekreationsidrotten låg på det "nöjsamma".

Om skillnaden mellan rekreations- och motionsidrotten var relativt blygsamma så framstod tävlingsidrotten i den Engströmska tappningen som något distinkt annorlunda. Här fanns den institutionella tillhörigheten och kraven på att följa regler och normer. Detta innebar att "individen måste anpassas till idrotten och inte tvärtom, dvs att utgångspunkten tas i individens behov och önskemål”. (Engström 1989, s. 43) Tävlingsidrottaren lärde sig att betrakta kroppen som ett medel för att i konkurrens med andra nå framgång. Tävlandet och rangordningen av deltagarna utifrån prestation skulle, förklarade Engström, "säkerligen upplevas som brutal om den gjordes inom andra områden av vårt samhällsliv". (Engström 1989, s. 42) En tävlingsidrottare utan framgångar framstod som ointressant eller än värre, som "patetisk". Tävlingsidrotten bidrog också till att förstärka samhälleliga klasskillnader. Engström stödde sig bland annat på den franske sociologen Pierre Bourdieus forskning. "Bourdieu som i huvudsak utgår från franska förhållanden framhåller att tävlingsidrotten som system reproducerar och vidmakthåller klasskillnader.” (Engström 1989, s.73) Bourdieus analys rörde dock fransk idrott i allmänhet, inte idrottstävlandet specifikt, eller någon fransk "tävlingsidrott". Men allvarligast ändå var kanske att tävlingsidrotten enligt Engström inte fullt ut respekterade principen om människors lika värde. Före tävlingen var alla jämlikar. Men efteråt var det annorlunda. "Eftersom segraren i tävlingen värderas högre än alla andra så värderas tävlingsdeltagarna efter tävlingen olika. I denna mening strävar inte tävlingsidrotten efter människors lika värde." (Engström 1989, s. 109) De tre idrottsformerna - motionsidrott, rekreationsidrott och tävlingsidrott - framställdes av Engström som distinkta kroppsliga kulturyttringar som i och genom fysiska praktiker och värderingsmatriser, lärde utövaren hur han/hon skulle agera fysiskt och tänka och tala om fysiska aktiviteter. Vissa idrotter var tävlingsidrotter, fotboll exempelvis, medan andra var rekreations- och motionsidrotter (exempelvis brädsegling/"windsurfing").

Engströms klassifikationsmodell från 1989 kom att följas av ytterligare två klassifikationsmodeller, en 1999 bestående av sju praktiker inom "kroppsövningskulturen": fysisk träning, tävling och rangordning, lek och rekreation, utmaning och äventyr, färdighetsträning, estetisk verksamhet samt rörelse- och koncentrationsträning. År 2010 presenterade Engström den senaste modellen som nu bestod av (minst) tio idrottsliga logiker (begreppet logik ersatte nu praktik). Utgångspunkten i båda är, precis som med 1989 års modell, idrottens historiska framväxt och olika faser samt Bourdieus "resonemang om 'praktikernas logik"'. (Engström 2010, s. 41) Enligt 1999 års klassifikationsmodell fanns alltså sju idrottsliga praktiker med meningsbärande, reglerande logiker som präglade individens habitus. Enligt Engström hade detta 
habitusgörande under barn- och ungdomsåren en avgörande betydelse för hur individer senare i livet förhöll sig till fysisk aktivitet. Den som under denna formativa livsfas befunnit sig i en specifik idrottslig praktik, och hithörande meningsbärande logik, kom senare i livet att känna sig mest hemmastadd i densamma. En individ kunde under sin livstid i och för sig ägna sig åt olika praktiker där skilda principer för handling och meningsbärande dominerar "men inte sällan är det", som Engström skriver, "en praktik som är överordnad i en persons liv". (Engström 1999, s. 36)
En av Engströms praktiker, och som också tillskrevs särskild betydelse, var "tävling och rangordning”, eftersom denna praktik dominerade den föreningsbaserade barn- och ungdomsidrotten. Om relationen mellan praktikerna "tävling och rangordning" och "lek och rekreation" konstaterades helt kort att "rangordning och konkurrens är viktigare ingredienser i den moderna tävlingsidrotten än lekmomentet”. (Engström 1999, s. 26) Den teoretiska utgångspunkten innebär att praktiken "tävling och rangordning", barn och ungdomsårens dominerade praktik, spelar en viktig roll också för vuxenlivets idrottande då

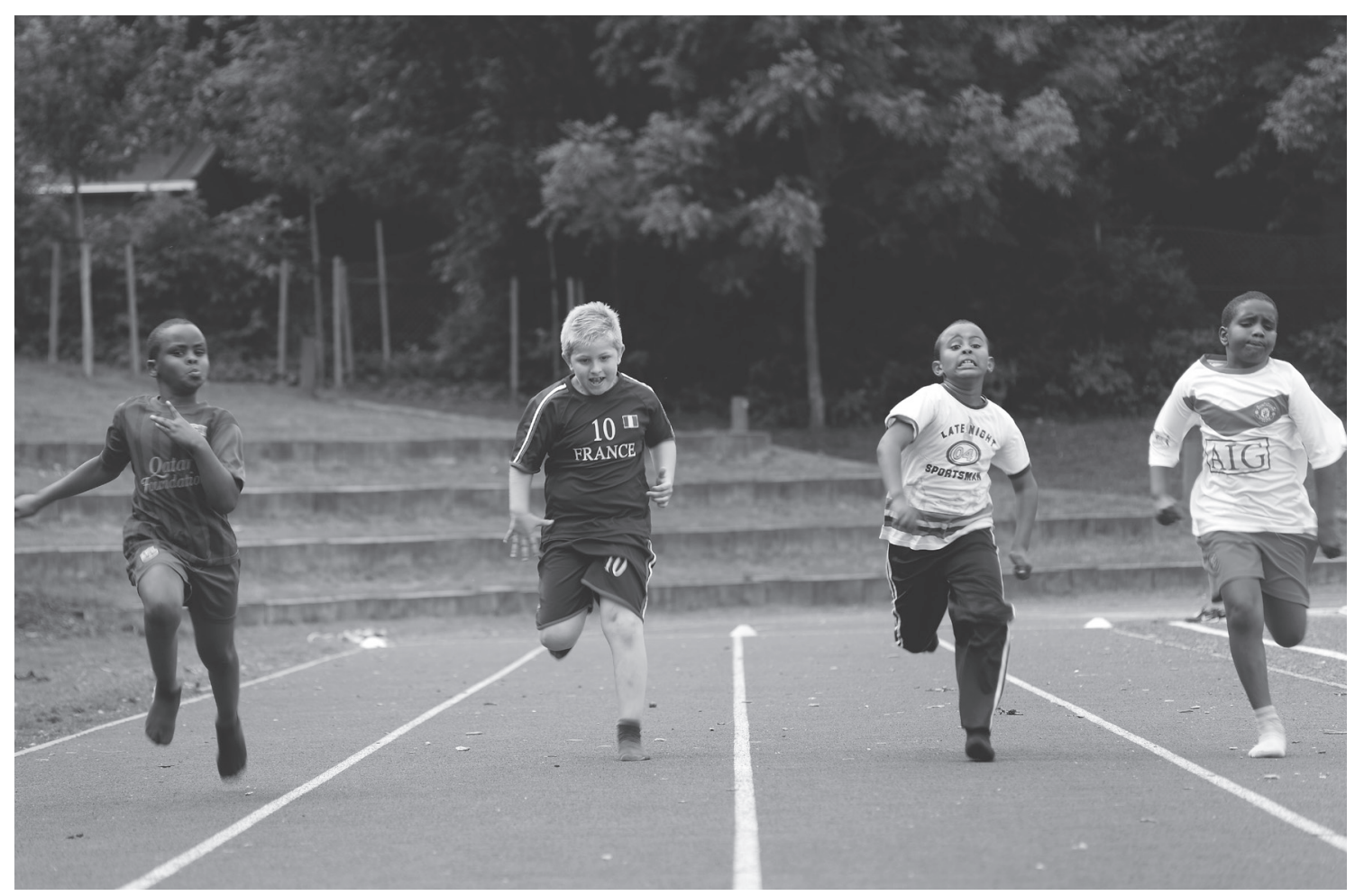

En svensk undersøgelse viser, at drenge profiterer så meget af daglig skoleidræt, at de kan opnå resultater, der er sammenlignelige med pigernes (Foto: Scanpix Denmark/Christian Als). 
man (delvis omedvetet) kommer att söka aktivitetsformer som harmoniserar med ens habitus. Det gäller exempelvis dem som i vuxen ålder vill engagera sig som idrottsledare då de kommer att söka sig till, men också understödja, föreningsidrottens dominerande praktik "tävling och rangordning". Men det rör också dem som i äldre ålder vill aktivera sig fysiskt för att må bra och söker, och erbjuds, ett åldersanpassat utbud som stavgång och lugna skidturer. Det sistnämnda kan innebära fysisk inaktivitet då stavgång och skidturer representerar praktiker med logiker som avviker från den som de är uppvuxna med ("tävling och rangordning"). Den fysiska inaktiviteten hos många äldre är alltså enligt Engström knutet till att man under barn och ungdomsåren vistats i en verksamhet med en praktik (logik) som i denna mening kan beskrivas som kontraproduktiv.

\section{POSITIVA ALTERNATIV TILL TÄVLINGSIDROTTEN}

De tävlingskritiska idrottsforskarna har på olika sätt verkat för en idrottslig kursändring i Sverige. Den dominerande ställning som praktiken "tävling och rangordning" haft skulle så långt som möjligt kompletteras eller ersättas av andra praktiker (med undantag för elitsatsande tonåringar och seniorer). Det här inkluderade en ganska skarpt och principiellt formulerad kritik av "tävlingsidrotten". Det här gällde även 1990och 2000-talens idrottsforskning, där "tävlingsidrott" användes som ett slags paraplybegrepp för idrotter där praktiken "tävling och rangordning" dominerat. År 2002 skrev exempelvis pedagogen Olle Åhs att "tävlingsidrotten, dvs. idrottsrörelsens aktiviteter för barn och ungdomar, kan [...] betraktas som en exponent för ett rådande individualistiskt värde- och trossystem. I detta trossystem höjer segraren sin status, dvs. sitt mänskliga värde, genom att besegra sina medtävlare.” (Åhs 2002, s. 243)
Kritiken av "tävlingsidrotten", och dess meningsbärande logiker, har också innehållit en mycket positiv värdering av lek och så kallad "spontanidrott" (praktiken "lek och rekreation"). ${ }^{10}$ Redan under 1970- och 1980-talen fanns det, som pedagogen Göran Patriksson påpekade, en romantisering av leken och krav på att den organiserade barn- och ungdomsidrotten borde innehålla mer lek utifrån antaganden om att detta skulle minska avhopp och idrottsligt utanförskap. (Patriksson 1987, s. 269) Enligt min mening har idealiseringen av leken, och spontanidrottspositivismen, ytterligare förstärkts under 1990- och 2000-talen. "Mera lek" inom barnidrotten - "lekfull" idrott - efterlyses av idrottsforskarna och beskrivs som ett medel att attrahera och behålla fler inom idrotten. Dikotomin lek (icke-tävling) - allvar (idrottstävling) användes flitigt. Lekfull idrott beskrevs som mindre kravfylld och ansågs underlätta inlärandet. Vuxenidrotten var dock ett problem då den gjort idrotten "för allvarlig". Spontanidrotten beskrevs på samma positiva sätt och kontrasterades mot tävlingsidrotten. Ett vanligt påstående var att barnens spontanidrott inte innehöll någon rangordning utifrån prestationsförmåga. ${ }^{11}$

"Att tävla med sig själv", istället för mot andra, framhålls också som en bra lösning på idrottsligt utanförskap och känslor av kompetensmässiga tillkortakommanden, inte bara för barn och ungdomar utan också för vuxna. Utgångspunkten är att risken för prestationsmässiga besvikelser, mindervärdeskänslor och dåligt självförtroende minskar om jaget utgör jämförelsepunkt. Ett närliggande synsätt framträder i idrottsforskarnas beskrivningar och analyser av så kallade "nya idrotter", ibland benämnda “äventyrsidrotter", “extremidrotter" etcetera, som påtagligt ofta är individuella idrotter där utövarna tar avstånd från den moderna idrotten 
och dess genomorganiserade tävlingsverksamhet. När utövarna själva, ofta pojkar och unga män, beskriver varför de håller på med brädsegling, skateboarding med mera, så liknar deras förklaringar de värden som tillskrivits praktikerna "lek och rekreation" samt "friluftsliv". Här betonas sinnliga upplevelser av fart och rytm, svårartikulerade "flow-känslor" och att det är snö, vindar, vågor och betongfundament som ska bemästras, inte mänskliga motståndare. Det är en individuell kamp mot naturelementen, och egna uppsatta mål, som ger aktiviteterna mål och mening. Empiriska studier av de "nya idrotterna" bekräftar dock inte fullt ut denna bild. Idrottsforskare som Johan Arnegård och Åsa Bäckström visar, vilket också ligger i linje med internationella studier, att det informella tävlandet - utan formaliserade regler och värderingskriterier - är både vanligt och viktigt och att det i dessa subkulturella motståndsgemenskaper finns prestationsbaserade hierarkier. (Arnegård 2006, Bäckström 2005, Wheaton 2004)

\section{PRESTATIONSJÄMFÖRELSER OCH MÄNNISKOVÄRDE}

Ett typiskt drag i de svenska idrottsforskarnas kritik av tävlingsidrotten är att idrottstävlingar reducerats till att endast omfatta formella tävlingar med systematiskt genomförda prestationsjämförelser av den typ som dominerat inom den moderna organisationsanknutna idrotten de senaste 100-150 åren. Här har funnits ett markant ointresse att studera och problematisera fysiska prestationsjämförelser av annat slag, exempelvis informella kraftmätningar inom spontanidrotten eller de som förekom före 1800-talets mitt. Utifrån olika stadieteorier och idrottsliga klassifikationsmodeller har dylikt definierats som något annat än idrottstävlingar/ tävlingsidrott. Här finns, när det gäller det hi- storiska perspektivet, ett anakronistiskt förhållningssätt, vilket också Alan Guttmanns teori om den moderna idrotten kritiserats för. (Carter \& Kruger 1990) Vad är då en idrottstävling?

Enligt min mening dominerar två slags idrottstävlingar; en där individer/kollaktiv tävlar mot varandra och en där individer/kollektiv tävlar bredvid varandra. Indelningen tar fasta på idrott som social praktik, och har, som jag ser det, betydande konsekvenser för hur tävlande men också idrottsligt samhandlande i stort kan förstås, även i ett långt historiskt tidsperspektiv. Dessa två tävlingsformer har filosofen Ingvar Johansson kallat "motkonkurrens" respektive "parallellkonkurrens". Löpning är exempel på parallellkonkurrens liksom tyngdlyftning och konståkning. Man kan i princip tävla med sig själv och då mäter man sig mot klockan, vikterna och stilpoängen. Resonemanget kan föras ytterligare ett steg då många idrotter - de som tillhör kategorin motkonkurrensidrotteer - för att överhuvudtaget kunna utövas, förutsätter en motpart. Idrottslig motkonkurrens förekommer med andra ord också utanför tävlingsarenorna. Att bryta arm med sig själv är svårt och badmintonspelaren vill ha en motpart på andra sidan nätet. Det förhåller sig på samma sätt med lagidrotter som fotboll och handboll. Parallellkonkurrensidrottare är inte lika beroende av andra människor i sitt idrottande och kan även idrotta utan att samtidigt mäta sig med en annan individ/annat kollektiv.

I den moderna idrottens organiserade idrottstävlingar finns regler och normativ tradition som anger vad som är bra och dåligt. Det betyder att det som värderas högt inom idrotten inte med automatik behöver göra det i andra sociala sammanhang. Den finländske filosofen Mikael Lindfelt beskriver idrotten som "koncentrerad livsförenkling”. Utanför tävlingsarenorna, vid 
informella "tävlingar", finns vanligen inga explicita värderingsmatriser av detta slag, utan här kan regler och bedömningskriterier variera, omförhandlas och se mycket olika ut. (Lindfeldt 2006)

Fysiska prestationsjämförelser, oavsett om de har hög organisationsgrad eller inte, innehåller alltså alltid ett moment av jämförelse. Det gäller också då man "tävlar med sig själv". Att tänka i jämförelser, kontrasterande bilder, liksom överhuvudtaget reflektera över likhet/ olikhet, har förmodligen funnits lika länge som människan. (Anderberg 2009) Mänskligt liv och social interaktion kännetecknas enligt Pierre Bourdieu av ett slags informellt tävlande: "socialt liv....är allas tävling mot alla". ${ }^{12}$ Att jämföra sig med andra, ökar självkännedomen. Det engelska ordet för tävling, competition, kommer från det latinska orden con petire som betyder "att söka tillsammans". Genom att mäta sina färdigheter mot en annan person skulle de bästa färdigheterna hos en själv upptäckas och i förlängningen ytterligare förädlas. (Jackson \& Csikszentmihaly 2000)

Tävlingar går ut på att finna vinnare; idrottstävlingen är per definition en meritokratisk arena omöjlig att förena med aktiviteter $\mathrm{i}$ vilka alla ska vara likvärdiga. Här avses med "likvärdiga" likhet i utfall, resultatlikhet. (Aas 2006) Att på detta sätt värdera mänskliga prestationer har som framgått tolkats som inhumant och som stridande mot principen om "alla människors lika värde" (som det t ex uttrycks i FN:s allmänna förklaring om mänskliga rättigheter). I den liberal-demokratiska traditionen anses dock inte prestationsvärderingar syftande till rangordningar kränka människovärdet eller strida mot "likavärdestesen". Erkännandet av ett grundläggande existensiellt människovärde, lika för alla, bör enligt filosofer inte tolkas som att alla människor i alla sammanhang är lika "värdefulla" eller att värderingar och rangordningar av människor och mänskliga egenskaper är något märkligt eller omoraliskt. Det är snarare tvärtom. (Hedenius 1982, s. 11 ff)

\section{AVSLUTNING}

Svenska idrottsforskare har sedan 1970-talet kritiserat tävlandet inom svensk idrott, inklusive den som förekommit i skolan. Det går så att säga en rak linje mellan Engström, Stockfelt i Stockholm 1970 och Apitszch i Umeå 2012. Det är dock viktigt att framhålla att tävlingskritiken generellt varit (är) mindre framträdande, eller helt saknats, hos de svenska idrottsforskare som utgått från Michael Foucaults teorier om kropp och disciplinering samt hos de forskare som fostrats i den västsvenska miljö som haft pedagogen Göran Patriksson som centralgestalt.

De tävlingskritiska idrottsforskarna tillskriver "tävlingsidrotten" ett innehåll överladdat på allvar, inhumana krav, primitiva känsloutlevelser och fåfäng statusjakt. Det som kännetecknar denna kritik, och som skiljer ut den från annan liknande kritik av idrotten, är utgångspunkten att det är tävlingsidrotten/praktiken "tävling och rangordning" $i$ sig som genom sin inneboende essens leder till problem av skilda slag. Lösningsförslagen illusterar också detta då man förordar idrott utan tävlingsinslag (Apitszch) och/eller fysiska aktivitetsformer med andra överordnade logiker, exempelvis "lek och rekreation" (Engström). Detta förklarar också den idealiserande lekretoriken och spontanidrottspositivismen (lek och spontanidrott har andra dominerande logiker).

Utrymmet medger inte en utförlig diskussion om de strukturella faktorer som bidrog till att denna tävlingskritiska tradition etablerades inom tongivande delar av svensk beteendeve- 
tenskaplig idrottsforskning och levt vidare till dags dato. ${ }^{13}$ I korthet menar jag att den är ett uttryck för en idrottsvetenskaplig diskurs, med rötter i en allmänpedagogisk strömning där leken och lustfyllt lärande värderats högt. ${ }^{14}$ Individers olikheter och skilda förmågor skulle tolereras och bejakas och inte värderas som bättre eller sämre, vilket inte harmoniserat med idrottens värderingsmatris. Detta värderelativistiska synsätt var också sannolikt ett uttryck för det senmoderna samhällets utopiska vision om ett socialt vara utan kollektivt påtvingade krav och begränsningar. Idrottsforskarna har, som sensibla uttolkare av unga människors tankar och behov, gjort sig till förespråkare för en senmodern idrott (individuell och nu-orienterad hedonisism). Här finns också spår av den (vänster-) politiskt färgade 1970-tals kritiken av idrotten i "konkurrenssamhället", med lös koppling till forskare som Bero Rigauer, Henning Eichberg, Seppo Hentilä, Johan Huizinga, Mihaly Csikszentmihalyi och, under de senaste 15-20 åren, den franske sociologen Pierre Bourdieu. Här finns möjligen också äldre historiska rötter då de svenska idrottsforskarnas kritik sedan 1970-talet är märkvärdigt lik den som linggymnastikens företrädare (traditionalisterna) för ungefär hundra år sedan riktade mot den framväxande moderna idrotten (det vill säga "tävlingsidrotten"). ${ }^{15}$ Det är mera osäkert om den tävlingskritiska traditionen kan kopplas till den svenska välfärdsstatens framväxt och jämlikhetsideal. ${ }^{16}$ Däremot har det funnits en strävan att distansera sig från Riksidrottsförbundet (föreningsidrotten/tävlingsidrotten), och deras ensidigt positiva syn på tävlan och färdighetsträning; att vara ett nödvändigt korrektiv så att säga. På detta sätt kunde också inomvetenskaplig legitimitet erhållas, viktigt under uppbyggnaden av ett nytt vetenskapligt fält.
Styrkan i ovanstående idrottsvetenskapliga diskurs visas inte minst av att begrepp som tävlingsidrott, tävling och lek, från och med 1980-talets slut, inte definierats särskilt distinkt, eller överhuvudtaget. Forskarna visste så att säga vad som avsågs med exempelvis "tävlingsidrott" (ibland med hänvisning till de svenska idrottshistorikernas uttolkning av internationella stadieteorier). Den moderna idrotten, tävling, träning eller vardagsmotionerande, har inte heller i någon högre grad problematiserats som sociala praktiker, snarare som individuella praktiker, där individens motiv, upplevelser och sociala status (genom konsumtion av idrott) stått i centrum. Kanske är detta ett uttryck för den egenheten att svensk beteendevetenskaplig idrottsforskning dominerats av psykologer och pedagoger, medan däremot sociologer nästan helt lyst med sin frånvaro.

\section{LITTERATURLISTA}

Aas, G.H. (2006). Likhet uten solidaritet? Idéhistoriske studier av karakterer $i$ utdanning og meritokrati, Institutionen för idéhistoria och vetenskapsteori, Göteborgs universitet: Göteborg.

Aggestedt, B. \& Tebelius, U. (1977). Barns upplevelser av idrott, Acta Universitatis Gothaburgensis, Göteborgs universitet: Göteborg.

Anderberg, T. (2009). Alla är vi kritiker, Atlas: Stockholm.

Arnegård, J. (2006). Upplevelser och lärande $i$ äventyrssport och skola, HLS Förlag, Lärarhögskolan i Stockholm: Stockholm.

Bairner, A. (2010)."What's Scandinavian about Scandinavian sport?", Sport in Society: Culture, Commerce, Media, Politics, 13:4, s. 734-743, Leicestershire. 
Brunnberg, H. (1976). Begreppet idrott hos människor inom idrotten, Pedagogiska institutionen, Stockholms universitet: Stockholm.

Bäckström, Å. (2005). Spår. Om brädsportkultur, informella lärprocesser och identitet, HLS förlag, Stockholm.

Carter, J.M. \& Kruger, A. (1990). Ritual and record: Sports Records and Quantification in Premodern Societies, Westport, Conn; Greenwood.

Eliasson, I. (2000). I skilda idrottsvärldar. Barn, ledare och föräldrar $i$ flick- och pojkfotboll, Umeå universitet: Umeå.

Engström, L.-M. (1975). Fysisk aktivitet under ungdomsåren, Stockholms universitet: Stockholm.

Engström, L.-M. (1989). Idrottsvanor i förändring, Högskolan för lärarutbildning i Stockholm, Institutionen för pedagogik: Stockholm.

Engström, L.-M. (1999). Smak för idrott, HLS Förlag: Stockholm.

Engström, L.-M. (2010). Smak för motion, Stockholms universitetsförlag: Stockholm.

Gesser, B. (1996), "Förord" i Pierre Bourdieu, Homo Academicus, B. Östlings förlag. Symposium: Eslöv.

Hedenius, I. (1982). Om människovärde, Bonniers: Stockholm.

Hjelm, J. (2010). "Den brutala tävlingsidrotten”, www.idrottsforum.org 2010-12-15.
Hjelm, J. (2011). "Historikerna och 'tävlingsidrotten'", Idrott, Historia \& Samhälle, Svenska idrottsföreningens årsskrift 2011, s 9-31: Stockholm.

Hjelm, J. (2012). "Idrott på lek och allvar", www. Idrottsforum.org, 2012-01-25.

Jackson, S.A. \& Csikszentmihaly, M. (2000). Flow och idrott, Brain books: Jönköping.

Janzon, B. (1978). Manschettyrken, idrott och hälsa. Studier kring idrottsrörelsen i Sverige, sär skilt Göteborg, intill 1900, Göteborgs universitet: Göteborg.

Karp, S. (2000). Barn, föräldrar och idrott, En intervjustudie om fostran inom fotboll och golf, Umeå universitet: Umeå.

Lindfeldt, M. (2006). Meningsskapande idrott: livsåskådningsrelevanta perspektiv och empiriska kontraster, Nya Doxa: Nora.

Lindroth, J. (1974). Idrottens väg till folkrörelse. Studier kring idrottsrörelsen till 1915, Studia Upsaliensia: Uppsala.

Nilsson, P. (1988). Tävlingsidrotten som uppfostringsmiljö, Högskolan för lärarutbildning i Stockholm: Stockholm.

Nilsson, P. (1993). Fotbollen och moralen. En studie av fyra allsvenska fotbollsföreningar, HLS Förlag: Stockholm.

Patrikssson, G. (1973). Idrottens historia i sociologisk belysning, Liber Förlag: Malmö. 
Patriksson, G. (1987). Idrottens barn - stress "utslagning”, Friskvårdscentrum: Stockholm.

Peterson, T. (2008). Föreningsfostran och tävlingsfostran, SOU 2008:59: Stockholm.

Redelius, K. (2002). Ledarna och barnidrotten. Idrottsledarnas syn på idrott, barn och fostran, HLS Förlag: Stockholm.

Sveriges offentliga utredningar (SOU). 1969:29, Idrott åt alla, Stockholm.

Sjöberg, L. (2011). "Vygotski goes neoliberal. Den ideale eleven och läraren i lärarutbildningens examinationspraktik", Utbildning \& Demokrati. Tidskrift för didaktik och utbildningspolitik, s 49-72, Vol 20, nr 22011.

Sutton-Smith, B. (2007). The Ambiguity of Play, Harvard University Press: Cambridge/London. Tidskrift i Gymnastik

Yttergren, L. (1996). Täflan är lifvet, Stockholmia förlag: Stockholm.

Wheaton, B. (2004). Understanding Lifestyle Sports. Consumption, identity and difference, Routledge: London/New York.

Åhs, O. (2002). "Idrott, människosyn och värdegrund”, i L.-M. Engström och K. Redelius (red.), Pedagogiska perspektiv på idrott, HLS Förlag: Stockholm.

\section{NOTER}

1 Tidskrift i Gymnastik, nr. 2 1970. s 39.

2 Tidskrift $i$ Gymnastik, nr. 1 1972, s 14

3 Umeå 2012-03-29. Undertecknad var närvarande. Se även artiklar i Västerbottens-Kuriren, 2012-05-04 och 2012-04-18 samt Erwin Apitzschs debattartikel i Svenska Dagbladet, 2011-09-03.

4 Sveriges offentliga utredningar (SOU), 1969:29, Idrott åt alla. För en utförlig redovisning av källor, litteratur och diskussion i detta avsnitt, se Hjelm 2010.

5 Med "utslagningen" inom idrotten avsågs vanligen att barn och ungdomar tidigt, och ofrivilligt, lämnade föreningsidrotten, kanske redan i 12-13 års ålder. Krav på specialisering, höga träningsdoser och "toppning" och liknande antogs ligga bakom.

6 Se exempelvis Patriksson 1973; Lindroth 1974 och Janzon 1978. För en utförlig redovisning av källor, litteratur och diskussion i detta avsnitt, se Hjelm 2011.

7 Se exempelvis Yttergren 1996.

8 Se exempelvis Eliasson 2009; Karp 2000; Redelius 2002. För en utförlig redovisning av källor, litteratur och diskussion i detta avsnitt, se Hjelm 2010 och 2012.

9 Pedagogen Per Nilsson, som hade Engström som handledare i slutet av 1980-talet, var en av dem som använde Engströms idrottsliga klassifikation, se Nilsson 1988 och Nilsson 1993.

10 För en utförlig redovisning av källor, litteratur och diskussion om lekretoriken, se Hjelm 2012.

11 Se t ex Tomas Peterson, Föreningsfostran och tävlingsfostran, SOU 2008:59, kapitel 6.

12 Citatet hämtat i Bengt Gesser, "Förord" i Pierre Bourdieu, Homo Academicus, Stockholm 1996, s 21.

13 För en fylligare diskussion, se Hjelm 2012.

14 Se exempelvis Sjöberg 2011.

15 Se exempelvis Wheaton 2004. Brian Sutton-Smith har uppmärksammat den likhet som finns mellan dagens och dåtidens idrottskritiker. "In games played for their own sake, courtly or gentlemanly virtues could prevail [...], whereas in games played for money, the desire to win prevailed over all other considerations. It was an aristocratic attitude designed to preserve the wealthy from association with the sweaty poorer classes. The current emphasis on play as fun can be seen to have similar connections to more affluent, or at least more elitist, perceptions of the good life." Sutton-Smith 2007:184.

16 Se exempelvis Alan Bairner, "What's Scandinavian about Scandinavian sport?", Sport in Society, Leicestershire 2010, 13:4 734-743. 